Kong. Res. J. 4(2): 162-166, 2017

ISSN 2349-2694

Kongunadu Arts and Science College, Coimbatore.

\title{
COMPARATIVE PHYTOCHEMICAL PROFILES OF TWO ACCESSIONS OF MEMECYLON EDULE ROXB. (MELASTOMATACEAE) BY GC-MS ANALYSIS
}

\author{
Saravanakumar, $\mathrm{K}$. \\ Botany Wing -DDE, Annamalai University, Annamalainagar-608002, Tamil Nadu, India.
}

\begin{abstract}
Memecylon edule Roxb. a member of Melastomataceae and a valuable Indian ethnomedicinal plant and there are two accessions of this species was investigated to determine the phytochemical constituents present in various extracts of the leaves through GC-MS analysis. Powdered leaf plant materials were subjected to successive extraction with organic solvents such as methanol by Soxhlet extraction method. In the present study, a total of phytocompounds, twenty eight from Acc.1 and twenty five from Acc. 2 were identified by GC-MS analysis using methanolic leaf extract, all the identified compounds were medicinally valuable for the treatment of various human ailments. In addition, all the phytochemical compounds were needed for further investigations on toxicological aspects for the development of new lead of therapeutic interest.
\end{abstract}

Keywords: Phytochemical profile, Memecylon edule, GC-MS analysis.

\section{INTRODUCTION}

The genus Memecylon L., belonging to the family Melastomataceae, is represented world over by around 250 species of shrubs and trees in the paleotropical region. Of which 30 species has been reported from India (Henry et al., 1989; Santapau and Henry, 1973) and 16 species from Tamil Nadu state (Nair and Henry, 1983). Also the genus Memecylon is represented by 39 species of which 21 are endemic to the country and the Western Ghats is reported to host 29 species (Viswanathan and Manikandan, 2001; Santhosh Kumar et al., 2003; Rajendraprasad et al., 2006; Murugan and Gopalan, 2006; Manickam et al., 2007). They are distributed in all types of habitats (Sivu et al., 2013). Memecylon species are utilized worldwide as timbers, ornamentals, source of edible fruits and yellow dye in addition to their medicinal properties (Mabberley, 2005).

The leaves of M. edule is used to heal the burning wounds without scar. The antiinflammatory, analgesic and antioxidant activities of the leaves used in traditional medicine in reliving inflammation and pain (Nualkew et al., 2009). Decoction of stem has also been relief fever symptoms of common diseases such as common cold, measles and chicken box (Karuppawamy, 2007). The antibacterial activity of seeds were evaluated (Elavazhagan and Arunachalam, 2010). After pursuit of published literature, so far meager work has been done regarding the phyto-chemical evaluation on this selected plant. Hence, in the present study GC-MS analysis was carried out with methanol extracts of the leaves of two accessions of
Memecylon edule Roxb. to examine the chemical constituents present in it.

\section{MATERIALS AND METHODS}

\subsection{Collection of plant materials and preparation of the extract}

The fresh leaves of Memecylon edule were collected from Acc.1.Authukurichi (Lat, $11.35{ }^{\circ} \mathrm{N}$; Long, $\left.79.31^{\circ} \mathrm{E}\right)$, Ariyalur District and Acc.2. Puthupattu, (12 $\left.05^{\prime} 74^{\prime \prime} \mathrm{N}, 7^{\circ} 86^{\prime} 93^{\prime \prime} \mathrm{E}\right)$ Villupuram District, Tamil Nadu, India. The specimen was botanically identified and confirmed by Rapinat Herbarium, St. Joseph's College, Tiruchirappalli. The preserved plant specimens were submitted to the Department of Botany, Annamalai University, Annamalainagar, Tamil Nadu for further reference. The leaves were chopped into small pieces, shadedried and coarsely powdered by using a pulverizor. The powdered leaf were subjected to successive extraction with organic solvents such as hexane chloroform and ethanol by Soxhlet method (Catherine et al., 1997). The extracts were then collected and distilled off on a water bath at atmospheric pressure and the last trace of the solvents was removed in vacuo and stored at $4^{\circ} \mathrm{C}$. They were used for GC-MS analysis.

2.2. Gas chromatography- mass spectrometry (GC-MS) analysis

GC-MS analysis was performed with GC-MS Clarus 500 Perkin Elmer Equipment. Compounds were separated on Elite-5 capillary column (Crossbond 5\% Phenyl 95\% dimethylpolysiloxane) Oven temperature was programmed as follows: 
isothermal temperature at $60^{\circ} \mathrm{C}$ then increased to $200^{\circ} \mathrm{C}$ at the rate of $10^{\circ} \mathrm{C} / \mathrm{min}$., then increased up to $280^{\circ} \mathrm{C}$ at the rate of $5^{\circ} \mathrm{C} / \mathrm{min}$. held for $9 \mathrm{~min}$. Ionization of the sample components was performed in the Electron energy $(70 \mathrm{eV})$. The helium was used as gas carrier $(1 \mathrm{ml} / \mathrm{min}$.$) , and 1.0 \mu \mathrm{L}$ of sample was injected. The detector was Mass detector Turbomass gold Perkin Elmer. The total running time for GC was $36 \mathrm{~min}$. and software Turbomass 5.2.0 was used in this GC-MS study (Manjamalai et al., 2010).

\subsection{Identification of compounds}

All the compounds were identified from methanol extracts based on direct comparison of the retention times and their mass spectra with the spectra of known compounds stored in the spectral database, National Institute Standard and technology (NIST) (Version year 2005).

\section{RESULT AND DISCUSSION}

The chemical constituents identified by the GC-MS analysis on methanolic leaf extract of two accessions of Memecylon edule were enumerated along with Molecular Formula (MF), Molecular Weight (MW), Retention Time (RT), and Peak area and Peak area (\%) is presented in Table-1. Of which nine compounds present in both the accessions of $M$. edule and are Furfural, Levoglucosenone, 1-Deoxy-daltritol, 4H-Pyran-4-one, 2,3-dihydro-3,5-,1,4,3,6Dianhydro-à-d-glucopyranose,1,2,3-Benzenetriol, 3, 7,11,15-Tetramethyl-2-hexadecen-1-ol and nHexadecanoic acid. Comparatively 1,2,3Benzenetriol show higher percentage in both accessions.

Table 1. Phytocompounds identified from the methanolic leaf extract of M. edule. (Acc.1. Authukurichi, Acc.2. Puthupattu)

\begin{tabular}{|c|c|c|c|c|c|}
\hline Sl.No. & Compound name & Formula & $\begin{array}{c}\text { Mol. } \\
\text { wroight }\end{array}$ & $\begin{array}{c}\text { Acc.1. } \\
\% \text { of peak } \\
\text { area }\end{array}$ & $\begin{array}{c}\text { Acc. } 2 \\
\% \text { of peak } \\
\text { area }\end{array}$ \\
\hline 1 & Furfural & $\mathrm{C}_{5} \mathrm{H}_{4} \mathrm{O}_{2}$ & 96 & 5.5959 & 1.5145 \\
\hline 2 & 2-Cyclopenten-1-one, 2-hydroxy- & $\mathrm{C}_{5} \mathrm{H}_{6} \mathrm{O}_{2}$ & 98 & 0.3292 & - \\
\hline 3 & 1-Benzoyl-3-amino-4-cyano-3-pyrroline & $\mathrm{C}_{12} \mathrm{H}_{11} \mathrm{~N}_{3} \mathrm{O}$ & 213 & 0.8871 & - \\
\hline 4 & 2(3H)-Furanone, 3-acetyldihydro- & $\mathrm{C}_{6} \mathrm{H}_{8} \mathrm{O}_{3}$ & 128 & 0.2274 & - \\
\hline 5 & Phentermin-propionyl & $\mathrm{C}_{13} \mathrm{H}_{19} \mathrm{NO}$ & 205 & 0.6349 & - \\
\hline 6 & cis-1,2-Dihydrocatechol & $\mathrm{C}_{6} \mathrm{H}_{8} \mathrm{O}_{2}$ & 112 & 0.392 & - \\
\hline 7 & 1,2-Butanediol, 1-phenyl- & $\mathrm{C}_{10} \mathrm{H}_{14} \mathrm{O}_{2}$ & 166 & 4.2074 & - \\
\hline 8 & Hydrouracil, 1-methyl- & $\mathrm{C}_{5} \mathrm{H}_{8} \mathrm{~N}_{2} \mathrm{O}_{2}$ & 128 & 0.9593 & - \\
\hline 9 & Methyl 2-furoate & $\mathrm{C}_{6} \mathrm{H}_{6} \mathrm{O}_{3}$ & 126 & 0.8868 & - \\
\hline 10 & Levoglucosenone & $\mathrm{C}_{6} \mathrm{H}_{6} \mathrm{O}_{3}$ & 126 & 2.2612 & 0.179 \\
\hline 11 & 1-Deoxy-d-altritol & $\mathrm{C}_{6} \mathrm{H}_{14} \mathrm{O}_{5}$ & 166 & 0.224 & 0.7361 \\
\hline 12 & 4H-Pyran-4-one, 2,3-dihydro-3,5- & $\mathrm{C}_{6} \mathrm{H}_{8} \mathrm{O}_{4}$ & 144 & 2.6392 & 1.457 \\
\hline 13 & Benzoic acid, 2-hydroxy-, methyl ester & $\mathrm{C}_{8} \mathrm{H}_{8} \mathrm{O}_{3}$ & 152 & 0.1067 & - \\
\hline 14 & 1,4:3,6-Dianhydro-à-d-glucopyranose & $\mathrm{C}_{6} \mathrm{H}_{8} \mathrm{O}_{4}$ & 144 & 1.4487 & 0.5732 \\
\hline 15 & 2-Furancarboxaldehyde, 5-(hydroxymethyl)- & $\mathrm{C}_{6} \mathrm{H}_{6} \mathrm{O}_{3}$ & 126 & 13.488 & - \\
\hline 16 & 2-Methoxy-4-vinylphenol & $\mathrm{C} 9 \mathrm{H}_{10} \mathrm{O}_{2}$ & 150 & 0.3241 & - \\
\hline 17 & Hydroquinone & $\mathrm{C}_{6} \mathrm{H}_{6} \mathrm{O}_{2}$ & 110 & 7.3113 & - \\
\hline 18 & Methyl-à-d-ribofuranoside & $\mathrm{C}_{6} \mathrm{H}_{12} \mathrm{O}_{5}$ & 164 & 0.6927 & - \\
\hline 19 & 1,2,3-Benzenetriol & $\mathrm{C}_{6} \mathrm{H}_{6} \mathrm{O}_{3}$ & 126 & 29.278 & 17.066 \\
\hline 20 & $\begin{array}{l}\text { 1,3-Cyclohexanediol, } \quad \text { 4,6-dimethyl-2-nitro-, } \\
\text { diacetate (ester) }\end{array}$ & $\mathrm{C}_{12} \mathrm{H}_{19} \mathrm{NO}_{6}$ & 273 & 0.3964 & - \\
\hline 21 & Dodecanoic acid & $\mathrm{C}_{12} \mathrm{H}_{24} \mathrm{O}_{2}$ & 200 & 0.2861 & - \\
\hline 22 & D-Allose & $\mathrm{C}_{6} \mathrm{H}_{12} \mathrm{O}_{6}$ & 180 & 15.256 & 16.808 \\
\hline 23 & Benzeneacetic acid, 4-hydroxy-3-methoxy- & $\mathrm{C}_{9} \mathrm{H}_{10} \mathrm{O}_{4}$ & 182 & 2.7237 & - \\
\hline 24 & $\begin{array}{l}\text { 2-Cyclohexen-1-one, } \\
\text { 3,5,5-trimethyl- }\end{array}$ & $\mathrm{C}_{13} \mathrm{H}_{22} \mathrm{O}_{2}$ & 210 & 1.9662 & - \\
\hline 25 & 3,7,11,15-Tetramethyl-2-hexadecen-1-ol & $\mathrm{C}_{20} \mathrm{H}_{4} \mathrm{O}_{0}$ & 296 & 0.6571 & 0.1904 \\
\hline 26 & 3,5-Dimethoxy-4-hydroxyphenylacetic acid & $\mathrm{C}_{10} \mathrm{H}_{12} \mathrm{O}_{5}$ & 212 & 0.6745 & - \\
\hline 27 & n-Hexadecanoic acid & $\mathrm{C}_{16} \mathrm{H}_{32} \mathrm{O}_{2}$ & 256 & 5.168 & 9.6491 \\
\hline 28 & cis-9-Hexadecenal & $\mathrm{C}_{16} \mathrm{H}_{30} \mathrm{O}$ & 238 & 0.9771 & - \\
\hline 29 & 2,10-Dodecadien-1-ol, 3,7,11-trimethyl-, & $\mathrm{C}_{15} \mathrm{H}_{28} \mathrm{O}$ & 224 & - & 3.2083 \\
\hline
\end{tabular}




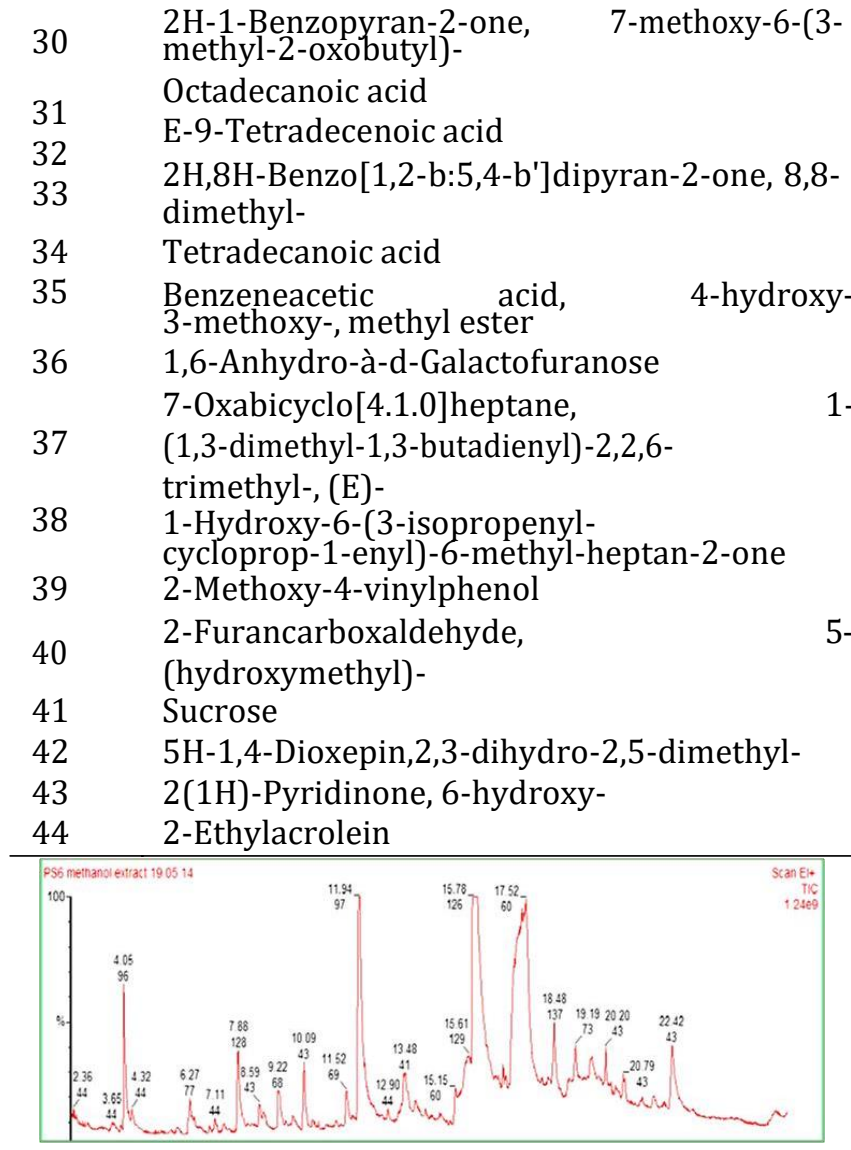

Fig. 1. GC-MS Chromatogram of methanolic leaf extract of M. edule (Acc.1. Authukurichi).

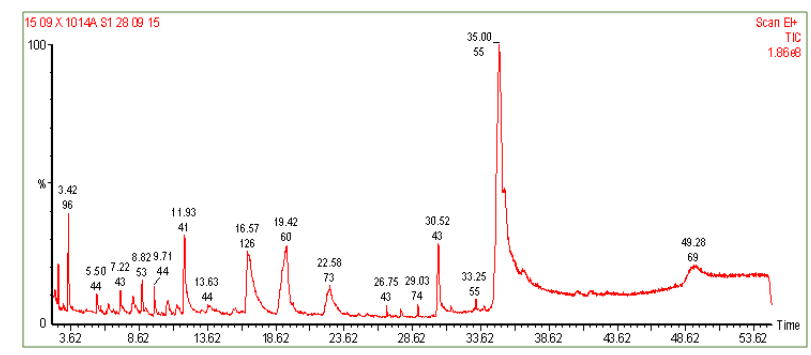

Fig. 2. GC-MS Chromatogram of methanolic leaf extract of M. edule (Acc.2. Puthupattu).

Plants serve as vast source for varied phytoconstituents exhibiting varied pharmacological property. Identifying such potential plants is of significance in medicine. In this connection, in the present study the methanolic leaf extract of two accessions of $M$. edule contains various phytocompounds. Secondary metabolites have proven to be medicinal in nature. They have various protective and therapeutic effects, which prevent diseases and maintain a state of well-being (Oyetayo, 2007).

$\begin{array}{cccc}\mathrm{C}_{15} \mathrm{H}_{16} \mathrm{O}_{4} & 260 & - & 0.2698 \\ \mathrm{C}_{18} \mathrm{H}_{36} \mathrm{O}_{2} & 284 & - & 1.0947 \\ \mathrm{C}_{14} \mathrm{H}_{26} \mathrm{O}_{2} & 226 & - & 4.1895 \\ & & & 0.2698 \\ \mathrm{C}_{14} \mathrm{H}_{12} \mathrm{O}_{3} & 228 & - & 0.3379 \\ \mathrm{C}_{14} \mathrm{H}_{28} \mathrm{O}_{2} & 228 & - & 0.1605 \\ \mathrm{C}_{10} \mathrm{H}_{12} \mathrm{O}_{4} & 196 & - & 10.409 \\ \mathrm{C}_{6} \mathrm{H}_{10} \mathrm{O}_{5} & 162 & - & 1.7445 \\ \mathrm{C}_{15} \mathrm{H}_{24} \mathrm{O} & 220 & - & \end{array}$

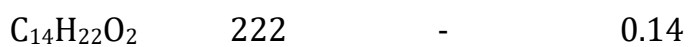

$\begin{array}{llll}\mathrm{C}_{9} \mathrm{H}_{10} \mathrm{O}_{2} & 150 & - & 0.1694\end{array}$

$\begin{array}{lllll}5- & \mathrm{C}_{6} \mathrm{H}_{6} \mathrm{O}_{3} & 126 & - & 9.3267\end{array}$

$\begin{array}{llll}\mathrm{C}_{12} \mathrm{H}_{22} \mathrm{O}_{11} & 342 & - & 2.1644\end{array}$

$\begin{array}{llll}\mathrm{C}_{7} \mathrm{H}_{12} \mathrm{O}_{2} & 128 & - & 1.5161\end{array}$

$\begin{array}{llll}\mathrm{C}_{5} \mathrm{H}_{5} \mathrm{NO}_{2} & 111 & - & 0.2702\end{array}$

$\begin{array}{llll}\mathrm{C}_{5} \mathrm{H}_{8} \mathrm{O} & 84 & - & 0.1516\end{array}$

These compounds are known to be biologically active. Tannins have been found to form irreversible complexes with proline-rich proteins (Hagerman and Butler, 1981) resulting in the inhibition of the cell protein synthesis. Tannins have important roles such as stable and potent antioxidants (Trease and Evans, 1983). Herbs that have tannins as their main component are astringent in nature and are used for treating intestinal disorders such as diarrhoea and dysentery (Subhuti Dharmananda, 2003). Presence of Hexadecanoic acid, showing Antioxidant, Antiandrogenic, Hypocholesterolemic activities and used as nematicide, pesticide, lubricant, also it is an hemolytic 5-Alpha reductase inhibitor. Flavonoids have been referred to as nature's biological response modifiers because of strong experimental evidence of their inherent ability to modify the body's reaction to allergen, virus and carcinogens. They show antiallergic, anti-inflammatory, anti- microbial and anticancer activity (Cushnie and Lamb, 2005; De Sousa et al., 2007).

Tannins are known to possess general antimicrobial and antioxidant activities (Rievere et al., 2009). Recent reports show that tannins may have potential value as cytotoxic and antineoplastic agents (Aguinaldo et al., 2005). Other compounds like saponins also have anti-fungal properties (Mohanta et al., 2007). Saponins are a mild detergent used in intracellular histochemistry staining to allow antibody access to intracellular proteins. In medicine, it is used in hyper cholestrolaemia, hyperglycemia, antioxidant, anticancer, anti- 
inflammatory and weight loss, etc. It is also known to have anti-fungal properties (De-Lucca et al., 2005). Saponins have been implicated as bioactive antibacterial agents of plants (Mandal et al., 2005; Manjunatha, 2006). Plant steroids are known to be important for their cardiotonic activities, possess insecticidal and anti- microbial properties. Plant derived natural products such as flavonoids, terpenoids and steroids etc have received considerable attention in recent years due to their diverse pharmacological properties including antioxidant and antitumor activity. Phenolic phytochemicals have antioxidative, antidiabetic anticarcinogenic, antimicrobial, antiallergic, antimutagenic and anti-inflammatory (Arts and Hollman, 2005; Scalbert et al., 2005). The present report correlates along with the above bioactivities and phytocompounds by the earlier reports in the leaf extracts of Memecylon umbellatum (Murugesan et al., 2011; Bharathi et al., 2015).

\section{CONCLUSION}

The presence of various bioactive compounds present in the leaves of M. edule justifies the use of for various ailments by traditional practitioners. However, isolation of individual phytochemical compound will subjecting it to biological activity will definitely give fruitful results. It could be concluded that Memcylon edule contains various bioactive compounds. However, further studies will need to be undertaken to ascertain fully its bioactivity, toxicity profile, effect on the ecosystem and agricultural products.

\section{REFERENCES}

Aguinaldo, A.M., El-Espeso, B.Q. Guovara and M. Nanoto, (2005). Phytochemistry. In: Guevara, BQ. (eds.), A guide book to plant screening phytochemical and biological. Manila: University of Santo Tomas.

Arts, I.C. and P.C. Hollman, (2005). Polyhenols are disease risk in epidemiological studies. Amer. J. Clin. Nut 81: 317-325.

Bharathi, T.R., M.C. Madhusudhan, P.M. Pradeep Kumar, S. Chandra Nayaka and H.S. Prakash, (2015). Antimicrobial Potential of Memecylon L. species from Western Ghats against clinical isolates of pathogenic bacteria. Research $\mathrm{J}$. Pharm. Biol. Chem. Sci 6(4): 1280-1287.

Catherine, A., E. Rice, J.M. Nicholas and P. George, (1997). Trends Plant Sci 2(4): 152-158.

Cushnie, T.P.T. and A.J. Lamb, (2005). Antimicrobial activity of flavonoids. Int. J. Antimicrob. Agents 26(5): 343-356.
De Sousa, R., R, Queiroz, K.C, Souza, A.C, Gurgueira, S.A, Augusto, A.C, Miranda, M.A, et al. (2007). Phosphoprotein levels, MAPK activities and NF kappa B expression are affected by fisetin. J. Enzyme Inhib. Med. Chem 22(4): 439-444.

De-Lucca, A., T. Cleveland, K. Rajasekara, S. Boue and R. Brown, (2005). Fungal properties of CAY-1, a plant saponin, for emerging fungal pathogens. $45^{\text {th }}$ inter science conference in antimicrobial agents and chemotherapy abstract.; p. 180.

Elavazhagan, T. and K.D. Arunachalam, (2010). Phytochemical and antibacterial studies of seed extract of Memecylon edule. Int. J. Eng. Sci. Tech 2(4): 498-503.

Hagerman, A.E. and I.G. Butler, (1981). J. Biol. Chem 256: 4494-4497.

Henry, A.N., V. Chithra, and N.P. Balakrishnan, (1989). Flora of Tamil Nadu. Series 1. Vol. 3. Botanical Survey of India, Coimbatore, India.

Karuppawamy, S. (2007). Medicinal plants used by Paliyan tribes of Sirumalai hills of Southern India. Indian Nat. Prod. Rad 6: 436-442.

Mabberley, D.J. (2005). The Plant Book, 2nd (eds.), Cambridge University Press, UK: p. 449.

Mandal, P., S.P. Sinha Babu and N.C. Mandal, (2005). Antimicrobial activity of Saponins from Acacia auriculiformis. Fitoterapia 76(5): 462-565.

Manickam, V.S., C. Murugan, G.J. Jothi and V. Sunderesan, (2007). Memecylon courtallense - A new species (Melastomataceae) from Courtallam Hills of Tamil Nadu, India. Indian J. For 30(1): 77-80.

Manjamalai, A., R.S.S.Singh, C. Guruvayoorappan and V.M. Berlin Grace, (2010). Global J. Biotechnol. Biochem 5(2): 120-128.

Manjunatha, B.K. (2006). Antibacterial activity of Pterocarpus santalinus. Ind. J. Pharm. Sci 68(1): 115-116.

Mohanta, T.K., J.K. Patra, S.K. Rath, D.K. Pal and H.N. Thatoi, (2007). Evaluation of antimicrobial activity and phytochemical screening of oils and nuts of Semicarpus anacardium L.f. Sci. Res. Essay 2(11): 486-490.

Murugan, C. and R. (2006). Gopalan Four new additions to Indian Memecylon $\mathrm{L}$. (Melastomataceae) from South India. Indian J. For 29(1): 105-108.

Murugesan, S., R. Vijayakumar and A. Panneerselvam, (2011). Evaluation of 
Phytochemical Constituents from the Leaves of Memecylon umbellatum Burm.f. Research J. Pharm. Biol. Chem. Sci 2(4): 1145-1152.

Nair, N.C. and A.N. Henry, (1983). Flora of Tamil Nadu. Ser. 1. Vol. 1. Botanical Survey of India, Coimbatore, India.

Nualkew, S., K. Rattanmanee, A. Thongpraditchote, Y. Wongkrajang and A. Nahrstedt, (2009). Antiinflammatory, analgesic and wound healing activities of the leaves of Memecylon edule Roxb. J. Ethnopharmacol 121(2): 278-281.

Oyetayo, V.O. (2007). Comparative studies of the phytochemical and antimicrobial properties of the leaf, and tuber of Anchomanes difformis. J. Pharmacol. Toxico 2(4): 407-410.

Rajendraprasad, M., S.L. Prathapan, A.G. Pandurangan and T. Shaju, (2006). Memecylon royenii Blume. (Melastomataceae): A new record for India. Indian For 132(2): 229-232.

Rievere, C., J.H. Van Nguyen, L. Pieters, B. Dejaegher, Y.V. Heyden and C.V. Minh, et al. (2009). Polyphenols isolated from antiradical extracts of Mallotus metcalfianus. Phytochem 70: 86-94.

Santapau, H. and A.N. Henry, (1973). A Dictionary of Flowering Plants in India. Council of Scientific and Industrial Research, New Delhi; pp. 1-198.
Santhosh Kumar, E.S., R. Antony and A.C. Shanavas Khan, (2003). Memecylon agastyamalaianum (Melastomataceae), a new species from India. Bot. Bull. Acad 44: 175-177.

Scalbert, A., C. Manach, C. Morand, C. Remesy and L. Jimenez, (2005). Dietary polyhenols and the prevention of diseases. Cri. Rev. Food Sci. Nutr 45: 287-306.

Sivu, A.R., N.S. Pradeep, K.B. Rameshkumar and A.G. Pandurangan, (2013). Evaluation of phytochemical, antioxidant and antimicrobial activities of Memecylon L. species from Western Ghats. Indian J. Nat. Prod. Res 4(4): 363-370.

Subhuti Dharmananda, (2003).Gallnuts and the Uses of Tannins in Chinese Medicine- A paper delivered at Institute for Traditional Medicine, Portland, Oregon.

Trease, G.E. and W.C. Evans, (1983). Textbook of Pharmacognosy $12^{\text {th }}$ (eds.). Balliere, Tindall, London.; pp. 343-383.

Viswanathan, M.B. and U. Manikandan, (2001). A new species, Memecylon mundanthuraianum of Melastomataceae from India. Nordic J. Bot 21(3): 259-262. 